\title{
Performance of Broilers Fed Diets Containing Natural Growth Promoters
}

Author(s)

Pelicano ERL

Souza PA

Souza HBA

Oba A

Norkus EA

Kodawara LM

Lima TMA

Departamento de Tecnologia

Faculdade de Ciências Agrárias e Veterinárias Unesp

\section{ABSTRACT}

The present study evaluated the effect of different probiotics on the performance of broiler chickens. A thousand and fifty one-day-old male Cobb chicks were distributed in a completely randomized design in a 3 $x 2+1$ factorial arrangement ( 3 probiotics sources in the diet, 2 probiotics concentrations in drinking water and 1 control group), with 5 repetitions of 30 birds per parcel. The results showed better feed conversion $(p<0.01)(1-21,22-35$ and $1-45$ days $)$ and weight gain $(p<0.05)(22-35$ and 1-45 days) in the control group in relation to the groups receiving probiotics. The use of Bacillus subtilis in the diet improved $(p<0.05)$ feed conversion during the growing phase, but this was not seen in the following period. Thus, it was concluded that probiotics supplementation had no beneficial effects on the performance.

\section{INTRODUCTION}

The aims of the modern broiler industry are to decrease production costs with high productivity by means of adequate genetics, nutrition and management procedures. Thus, the poultry industry has used for many years some tools that resulted in improved growth and higher yield, among which the use of growth promoter additives (Pelicano et al., 2002).

Antibiotic utilization dates from the 50s' and positive results of production indexes were rapidly achieved, which lead to an indiscriminate and abusive use of antibiotics, and consequently the presence of residues in the meat and meat products. There are strong microbiological and clinical evidences for a possible relationship between the use of antibiotics in animal production and the increasing number of resistant bacteria in humans (Padilha, 2000).

Therefore, the indiscriminate use of such drugs was questioned. In addition to the problems already mentioned, there was the supposition that such additives caused the destruction not only of pathogenic bacteria, but also of beneficial bacteria. This could result in unbalanced symbiosis between the desirable microbiota and the host (Mulder, 1991).

International health organisms and authorities such as the Food and Drug Administration (FDA) are more concerned about animal diets containing antibiotics since the $70 \mathrm{~s}^{\prime}$ and the $80 \mathrm{~s}^{\prime}$. Rigorous guidelines on the use of these substances in feed formulations for animals were established in developed countries. In Brazil, the Ministry of Agriculture has prohibited the use of many antibiotics in animal diets since the 90s' (Menten, 2002).

In face of such problems and regulations, researchers began to evaluate potential alternatives to antibiotics worldwide; if antibiotics were simply to be taken out of diets, the production of animal protein might be seriously affected as a consequence of poorer animal 
Pelicano ERL, Souza PA, Souza HBA, Oba A, Norkus EA, Kodawara LM, Lima TMA
Performance of Broilers Fed Diets Containing Natural Growth Promoters performance. The interest was then focused on one of the natural defense mechanisms of animals, to which little attention had been given until then: the so-called probiotics (Biotecnal, s.d.). Probiotics are comprised of the populations of non-pathogenic microorganisms that reside in the digestive tract of all domestic animals and men.

Probiotics are classified as GRAS (Generally Recognized as Safe) by the FDA. The concept of their use relates to maintaining the equilibrium of the intestinal microflora by the addition of beneficial microorganisms (Goldin, 1998).

Many studies have reported the benefits of probiotics utilization on productive indexes (Wolke et al., 1996; Cavazzoni et al., 1998; Jin et al., 1998, Sogaard \& Suhr-Jessen, 1999; Besnard et al., 2000; Campos et al., 2002). On the other hand, Barrow (1992) and Loddi et al. (2000) found no beneficial effects.

Since the efficacy of such products was still not confirmed by consistent data, further studies should be carried out aiming to assure future utilization of probiotics as an alternative to traditional growth promoters. The present study evaluated the utilization of different probiotics in the diets and drinking water and the effects on the performance of broilers.

\section{MATERIAL AND METHODS}

\section{Experimental design and treatments}

The experiment was conducted at the poultry experimental facility from Faculdade de Ciências Agrárias e Veterinárias from UNESP, Campus Jaboticabal, SP, Brazil. One thousand and fifty oneday-old male chicks from Cobb strain were used. Birds were vaccinated against Marek's disease and fowl pox at the hatchery. Chicks were assigned to 35 pens $(2.75 \mathrm{~m} \times 1.4 \mathrm{~m})$ in the experimental poultry house. There were 30 birds/pen, in a final density of 8 birds $/ \mathrm{m}^{2}$. Infrared lamps were used to provide initial heating. After the second week of age, initial drinkers and feeders were replaced by automatic drinkers and tubular feeders with capacity for $20 \mathrm{~kg}$.

Ambient temperature and relative humidity was recorded daily and adequate curtain and fan management was performed to assure adequate environment conditions to the birds. Feed and water were given ad libitum.

In order to prevent cross-contamination of diets with microorganisms, diets were handled one at a time and with separate scoops. Besides, separate cleaning material was used for the drinkers of different treatments and disposable plastic booties were used when entering each pen, so as to prevent microbial contamination between treatments.

The broilers were distributed in a randomized design in a $3 \times 2+1$ factorial arrangement. There were three probiotics sources added to the diet (Bacillus subtilis, Bacillus subtilis and Bacillus licheniformis; and Saccharomyces cerevisiae), two concentrations of probiotics in drinking water (with and without probiotics) and one control group (no probiotics added), with a total of 7 treatments and 5 replications with 30 birds.

The treatments were as follows: Control (no antibiotic or probiotics added); addition of Bacillus subtilis-based probiotics to the diet $\left(10^{10}\right.$ colony forming units (CFU)/g product) and no probiotics added to the drinking water; addition of Bacillus subtilis-based probiotics to the diet $\left(10^{10} \mathrm{CFU} / \mathrm{g}\right.$ product) and Lactobacillus-based probiotics to the drinking water (Lactobacillus reuteri, $6.6 \times 10^{9} \mathrm{CFU} / \mathrm{g}$ product; Lactobacillus johnsonii, $3.3 \times 10^{9}$ CFU/g product); addition of Bacillus-based probiotics to the diet (Bacillus subtilis, $1.6 \times 10^{9} \mathrm{CFU} / \mathrm{g}$ product; Bacillus licheniformis, $1.6 \times 10^{9} \mathrm{CFU} / \mathrm{g}$ product) and no probiotics added to the drinking water; addition of Bacillus-based probiotics to the diet (Bacillus subtilis, $1.6 \times 10^{9} \mathrm{CFU} / \mathrm{g}$ product, Bacillus licheniformis, $1.6 \times 10^{9} \mathrm{CFU} / \mathrm{g}$ product) and Lactobacillus-based probiotics to the drinking water (Lactobacillus reuteri, $6.6 \times 10^{9} \mathrm{CFU} / \mathrm{g}$ product; Lactobacillus johnsonii, $3.3 \times 10^{9}$ CFU/g product); addition of Saccharomyces-based probiotics to the diet (Saccharomyces cerevisiae, $8 \times 10^{9} \mathrm{CFU} / \mathrm{g}$ product) and no probiotics added to the drinking water; and finally addition of Saccharomyces-based probiotics to the diet (Saccharomyces cerevisiae, $8 \times 10^{9}$ CFU/g product) and Lactobacillus-based probiotics to the drinking water (Lactobacillus reuteri, $6.6 \times 10^{9} \mathrm{CFU} / \mathrm{g}$ product; Lactobacillus johnsonii, $3.3 \times 10^{9} \mathrm{CFU} / \mathrm{g}$ product).

The commercial products containing the microorganisms were added to the diet following the instructions given by the manufacturers:

- Bacillus subtilis - based probiotics added to the diet at $300 \mathrm{~g}$ of product per ton of diet, throughout the rearing period (1-45 days of age);

- Probiotics based on a mixture of Bacillus subtilis and Bacillus licheniformis added to the diet at $1,000 \mathrm{~g}$ of product per ton of starter diet (1-21 days of age) and $400 \mathrm{~g}$ of product per ton of diet until slaughter age (22-45 days of age); 
- Saccharomyces cerevisiae - based probiotics added to the diet at 2,000 $\mathrm{g}$ of product per ton of starter diet (1-21 days of age), 1,000 g product per ton of grower diet (22-35 days of age) and $800 \mathrm{~g}$ product per ton of finisher diet (36-45 days of age);

- Lactobacillus reuteri and Lactobacillus johnsonii - based probiotics added to drinking water at $25 \mathrm{~g}$ for each 5,000 chicks, at the first day of age.

\section{Experimental Diets}

Experimental feeds (Table 1) were based on corn, soybean meal, soybean oil, dicalcium phosphate, calcitic limestone, salt, synthetic amino acid and vitamin-mineral supplement. The nutritional levels for the three phases of rearing were as recommended by NRC (1994).

Table 1 - Composition of experimental diets.

\begin{tabular}{|c|c|c|c|}
\hline Ingredients (\%) & $\begin{array}{l}\text { Initial } \\
1-21 \text { days) }\end{array}$ & $\begin{array}{l}\text { Growing } \\
\text { (22-35 days) }\end{array}$ & $\begin{array}{c}\text { Final } \\
\text { (36-45 days) }\end{array}$ \\
\hline Corn & 52.94 & 60.77 & 66.25 \\
\hline Soybean meal & 40.10 & 32.20 & 27.00 \\
\hline Soybean oil & 2.40 & 3.30 & 3.70 \\
\hline Dicalcium phosphate & 1.95 & 1.43 & 1.18 \\
\hline Calcitic limestone & 1.03 & 1.19 & 1.10 \\
\hline Salt & 0.40 & 0.34 & 0.25 \\
\hline Vitamin-mineral supplement & 0.80 & 0.60 & 0.40 \\
\hline Inert & 0.20 & 0.10 & 0.08 \\
\hline Methionine & 0.18 & 0.07 & 0.04 \\
\hline \multirow[t]{2}{*}{ Total } & 100.00 & 100.00 & 100.00 \\
\hline & \multicolumn{3}{|c|}{ Nutritional Levels } \\
\hline ME (kcal/kg) & 2,9 & 3,100 & 3,200 \\
\hline $\mathrm{CP}(\%)$ & 23.00 & 20.00 & 18.00 \\
\hline Methionine (\%) & 0.537 & 0.388 & 0.333 \\
\hline Methionine + Cystine (\%) & 0.909 & 0.720 & 0.639 \\
\hline Lysine (\%) & 1.285 & 1.074 & 0.935 \\
\hline Calcium (\%) & 1.001 & 0.913 & 0.803 \\
\hline $\mathrm{P}$ available (\%) & 0.481 & 0.377 & 0.327 \\
\hline \multicolumn{4}{|c|}{ 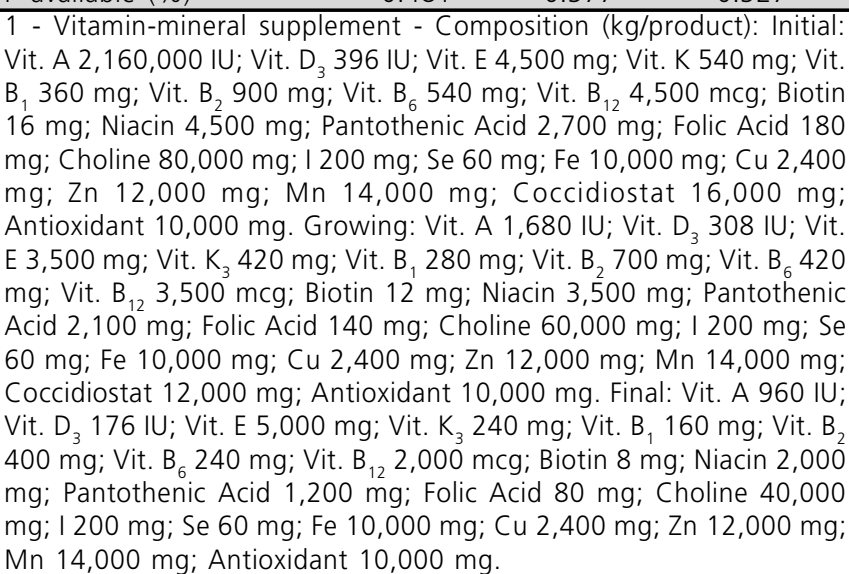 } \\
\hline
\end{tabular}

\section{Statistical Analysis}

Statistical analysis was performed using the software Estat 2.0 (1992), and differences between treatment means were evaluated by Tukey's test. Significance levels $(p<0.05$ and $p<0.01)$ are indicated.

\section{Evaluated Parameters}

Performance data were recorded in the periods from 1 to 21,22 to 35,36 to 45 and 1 to 45 days of age. Feed intake was determined for each repetition as the difference between the amount of feed supplied and the remaining feed at the end of each experimental period, and weight gain was calculated as the difference between the final and initial bird weight. Feed conversion was determined as the ratio between feed intake and weight gain at each phase of the experimental period and viability was determined as the number of birds produced at 45 days of age divided by the initial number of chicks $\times 100$.

\section{RESULTS AND DISCUSSION}

There was no significant interaction between the two factors, which indicates that probiotics utilization in the diet or in the drinking water had independent effects on the evaluated characteristics.

Feed intake was similar in the groups receiving probiotics and the control group (Table 2 ) in all rearing periods that were evaluated, corroborating previous results reported for feed intake at 21 days (Sato et al., 2002; Pelicano et al., 2004) and at 42 days of age (Mohan et al., 1996; Loddi, 2003).

There were also no differences among the groups fed different probiotics in the diets, and no differences when the groups fed probiotics only in the diet were compared with the groups given an association of products in the water and feed. Nevertheless, feed intake was slightly higher when an association of probiotics was administered. Maybe if probiotics based on Lactobacillus reuteriand Lactobacillus johnsoniihad been added to the drinking water for longer periods, significant differences in feed intake from 1 to 45 days of age would have been seen.

Table 3 shows that there were no differences in weight gain for birds receiving probiotics and the control group in the starter phase (1-21 days). These findings are similar to the results reported by Fethiere \& Miles (1987), Maiorka et al. (2001) and Sato et al. (2002). On the other hand, results were better in the control group during the growing period (22-35 days). Birds fed probiotics had lower feed intake $(p<0.05)$ 
Pelicano ERL, Souza PA, Souza HBA, Oba A, Norkus EA, Kodawara LM, Lima TMA
Performance of Broilers Fed Diets Containing Natural Growth Promoters
Table 2 - Feed intake of broilers fed probiotics in the diet and drinking water at different rearing phases.

\begin{tabular}{|c|c|c|c|c|}
\hline \multirow{2}{*}{$\begin{array}{l}\text { Evaluated } \\
\text { Parameter }\end{array}$} & \multicolumn{4}{|c|}{ Feed Intake (g) } \\
\hline & $1-21 d$ & $22-35 d$ & $36-45 d$ & $1-45 d$ \\
\hline \multicolumn{5}{|c|}{ Probiotics in Diet (A) } \\
\hline Bacillus subtilis & 897 & 1,944 & 1,785 & 4,626 \\
\hline B. subtilis $+B$. Licheniformis & 922 & 1,951 & 1,740 & \\
\hline Saccharomyces cerevisiae & 925 & 1,972 & 1,765 & 4,662 \\
\hline Test $\mathrm{F}$ & $1.40 \mathrm{~ns}$ & $0.36 \mathrm{~ns}$ & $0.59 \mathrm{~ns}$ & $0.19 \mathrm{~ns}$ \\
\hline LSD & 46.10 & 86.18 & 104.57 & 211.56 \\
\hline \multicolumn{5}{|c|}{ Probiotics in the drinking water (B) } \\
\hline No Probiotics & 905 & 1,957 & 1,755 & 4,617 \\
\hline L. reuteri + L. johnsonii & 924 & 1,955 & 1,771 & 4,650 \\
\hline Test F & $1.63 \mathrm{~ns}$ & $0.01 \mathrm{~ns}$ & $0.22 \mathrm{~ns}$ & $0.22 \mathrm{~ns}$ \\
\hline LSD & 31.16 & 58.25 & 70.68 & 143.00 \\
\hline \multicolumn{5}{|c|}{ Control vs Factorial } \\
\hline Control & 893 & 1,976 & 1,781 & 4,650 \\
\hline Factorial & 915 & 1,956 & 1,763 & 4,634 \\
\hline Test $\mathrm{F}$ & $1.17 \mathrm{~ns}$ & $0.29 \mathrm{~ns}$ & $0.15 \mathrm{~ns}$ & $0.03 \mathrm{~ns}$ \\
\hline$A \times B$ & $0.74 \mathrm{~ns}$ & $3.12 \mathrm{~ns}$ & $0.19 \mathrm{~ns}$ & $0.76 \mathrm{~ns}$ \\
\hline CV (\%) & 4.57 & 3.97 & 5.35 & 4.12 \\
\hline
\end{tabular}

Table 3 - Weight gain of broilers fed probiotics in the diet and drinking water at different rearing phases.

\begin{tabular}{|c|c|c|c|c|}
\hline \multirow[t]{2}{*}{ Evaluated Parameter } & \multicolumn{4}{|c|}{ Weight gain (g) } \\
\hline & $1-21 d$ & $22-35 \mathrm{~d}$ & $36-45 \mathrm{~d}$ & $1-45 d$ \\
\hline \multicolumn{5}{|c|}{ Probiotics in Diet (A) } \\
\hline Bacillus subtilis & 640 & 977 & 672 & 2,289 \\
\hline B. subtilis $+B$. Licheniformis & 646 & 947 & 671 & 2,264 \\
\hline Saccharomyces cerevisiae & 65 & & & 2,274 \\
\hline Test $\mathrm{F}$ & 0.58 & 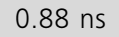 & ns & $0.14 \mathrm{~ns}$ \\
\hline LSI & 26.78 & 58.1 & 56.22 & 114.63 \\
\hline \multicolumn{5}{|c|}{ Probiotics in the drinking water (B) } \\
\hline No Probiotics & 643 & 964 & 659 & 2,266 \\
\hline L. reuteri + L. johnsonii & 649 & 963 & & 2,286 \\
\hline Test $\mathrm{F}$ & $0.50 \mathrm{~ns}$ & $0.00 \mathrm{~ns}$ & $0.67 \mathrm{~ns}$ & $0.28 \mathrm{~ns}$ \\
\hline & 18.10 & 39.31 & & 77.48 \\
\hline \multicolumn{5}{|c|}{ Control vs Factorial } \\
\hline Cont & 654 & $1021^{\mathrm{a}}$ & 702 & $2,377^{a}$ \\
\hline $\mathrm{Fact}$ & 646 & $964^{b}$ & 666 & $2,276^{b}$ \\
\hline Test $\mathrm{F}$ & $0.46 \mathrm{~ns}$ & $5.19 *$ & $2.15 \mathrm{~ns}$ & 4.13 * \\
\hline$A \times B$ & $0.79 \mathrm{~ns}$ & $2.10 \mathrm{~ns}$ & $0.04 \mathrm{~ns}$ & $0.74 \mathrm{~ns}$ \\
\hline CV (\%) & 3.74 & 5.40 & 7.56 & 4.52 \\
\hline
\end{tabular}

$\mathrm{a}, \mathrm{b}$ - For each independent factor, means followed by different letters within the column are different $(p<0.05)$ by Tukey's test. Test F: ns, non-significant; * $-p<0.05$. LSD - Least significant difference.

associated to poor feed conversion in almost all evaluated periods $(p<0.01)$, which were decisive to result in the lower weight gain $(p<0.05)$ seen in these birds. Although no significant differences in performance were observed between these groups in the finisher phase (36-45 days), the decrease $(p<0.05)$ in the growing period was enough to negatively influence the performance of birds fed probiotics in the total period of rearing (1-45 days). Such results corroborate the findings of Buenrostro \& Kratzer (1983) and Sugeta et al. (2004), but are nevertheless opposite to those reported by Santoso et al. (1995), Yeo \& Kim (1997), Cavazzoni et al. (1998) and Moreira et al. (2001).

According to Buenrostro \& Kratzer (1983), the decrease that was seen in performance when probiotics were given to birds might have resulted from a series of factors, among those, inadequate dosing of microorganisms, lack of sanitary challenge, as well as competition with the host for nutrients.

It was also observed that the utilization of the association of probiotics (water and feed) resulted in a slight increase of weight gain in the period from 1 to 45 days of age $(2,286 \mathrm{~g})$, when compared to the use in the diet only $(2,266 \mathrm{~g})$.

The groups fed the probiotics based on Bacillus subtilis in the diet had better feed conversion $(p<0.05)$ from 22 to 35 days (Table 4) compared to the other groups. However, the difference was not seen at the finisher phase (36 to 45 days) or at the total period of evaluation ( 1 to 45 days). Feed conversion was better $(p<0.05)$ in the control group compared to the other treatments in the periods from 1 to 21,22 to 35 and 1 to 45 days of age. The poorer feed conversion seen in the groups fed probiotics if compared to the control group evidences the reason for the lower weight gain indexes, since all treatments had similar feed intake. These findings are different from the results described by Jin et al. (1998) and Besnard et al. (2000). The authors reported worse feed conversion in the control group when compared to groups of broilers and turkeys fed probiotics based on Lactobacillus sp and Saccharomyces cerevisiae in the diets, respectively.

It is interesting to note that the negative performance results that were observed in the total period for birds fed probiotics may be due to the fact that the birds were reared in an environment with all measures needed to prevent diseases, and therefore with low challenge. According to some studies, results of probiotics utilization may not be so evident in conditions of minimal stress (Fox, 1988; Dale, 1992; Maruta, 1993). Therefore, it is supposed that an unbalance in the intestinal microbiota might have occurred as a consequence of the higher quantities of different microorganisms that were supplemented in the probiotics when compared to the normal levels found in the digestive tract. The microorganisms might have impaired the metabolization and absorption of the nutrients somehow and, consequently, might have had a negative effect on bird performance. According 
Pelicano ERL, Souza PA, Souza HBA, Oba A, Norkus EA, Kodawara LM, Lima TMA to Visek (1978), the microflora has diverse beneficial functions, such as increasing starch digestion, recovering endogenous nitrogen, facilitating mineral absorption and being involved in vitamin synthesis. Nevertheless, some other negative functions will decrease the nutrient absorption, such as increase in intestinal thickness and increased food passage rate (Visek, 1978). Besides, they compete with the host for nutrients and accelerate cellular turnover.

Table 4 - Feed conversion of broilers fed probiotics in the diet and drinking water at different rearing phases.

\begin{tabular}{|c|c|c|c|c|}
\hline \multirow[t]{2}{*}{ Evaluated Parameter } & \multicolumn{4}{|c|}{ Feed conversion } \\
\hline & $1-21 d$ & $22-35 d$ & $36-45 d$ & $1-45 d$ \\
\hline \multicolumn{5}{|c|}{ Probiotics in Diet (A) } \\
\hline Bacillus subtilis & 1.40 & $1.99 \mathrm{~b}$ & 2.66 & 2.02 \\
\hline B. subtilis $+B$. Licheniformis & 1.43 & $2.06^{a}$ & 2.60 & 2.04 \\
\hline Saccharomyces cerevisiae & 1.42 & $2.04 \mathrm{ab}$ & 2.69 & 2.05 \\
\hline Test $\mathrm{F}$ & $1.24 \mathrm{~ns}$ & $3.78 *$ & $1.22 \mathrm{~ns}$ & $1.37 \mathrm{~ns}$ \\
\hline LSD & 0.04 & 0.07 & 0.15 & 0.05 \\
\hline \multicolumn{5}{|c|}{ Probiotics in the drinking water (B) } \\
\hline No Probiotics & 1.41 & 2.03 & 2.67 & 2.04 \\
\hline L. reuteri + L. johnsonii & 1.43 & 2.03 & 2.63 & 2.03 \\
\hline Test $\mathrm{F}$ & $1.48 \mathrm{~ns}$ & $0.00 \mathrm{~ns}$ & $0.62 \mathrm{~ns}$ & $0.02 \mathrm{~ns}$ \\
\hline LSD & 0.03 & 0.04 & 0.10 & 0.03 \\
\hline \multicolumn{5}{|c|}{ Control vs Factorial } \\
\hline Control & $1.37^{a}$ & $1.94^{\mathrm{a}}$ & 2.54 & $1.96^{a}$ \\
\hline Factorial & $1.42 \mathrm{~b}$ & $2.03^{b}$ & 2.65 & $2.04^{b}$ \\
\hline Test $F$ & $7.90 * *$ & $11.05 * *$ & 2.56 ns 1 & $15.20 * *$ \\
\hline$A \times B$ & $0.02 \mathrm{~ns}$ & $0.28 \mathrm{~ns}$ & $0.01 \mathrm{~ns}$ & $0.28 \mathrm{~ns}$ \\
\hline CV $(\%)$ & 2.70 & 2.97 & 5.27 & 2.14 \\
\hline $\begin{array}{l}\text { a,b - For each independen } \\
\text { letters within the column are } \\
\text { F: ns, non-significant; * }-p< \\
\text { difference. }\end{array}$ & $\begin{array}{l}\text { ot factor, } \\
\text { e different } \\
\text { <.05; } * *\end{array}$ & $\begin{array}{l}\text { neans fo } \\
(p<0.05) \\
<0.01 .\end{array}$ & $\begin{array}{l}\text { wed by d } \\
\text { Tukey's t } \\
\text { - Least sic }\end{array}$ & $\begin{array}{l}\text { different } \\
\text { test. Test } \\
\text { ignificant }\end{array}$ \\
\hline
\end{tabular}

Viability was not significantly different among treatments. Nevertheless, it was better in the groups of birds fed probiotics and, among those, in the groups fed microorganisms based on Bacillus subtilis and Bacillus licheniformis (Table 5). Therefore, it seems that the microorganisms have stimulated the immune system of the birds, resulting in higher resistance against pathogens and consequently better viability. These findings corroborate the results reported by Leedle (2000) and Silva (2000), who suggested that the immunological status of the host is directly related to the intestinal microbiota, since the antigenic load resulting from these bacteria induce stimulation of the immune system. Some studies reported lower mortality indexes when probiotics were used (Henrique et al., 1998; Campos et al., 2002).

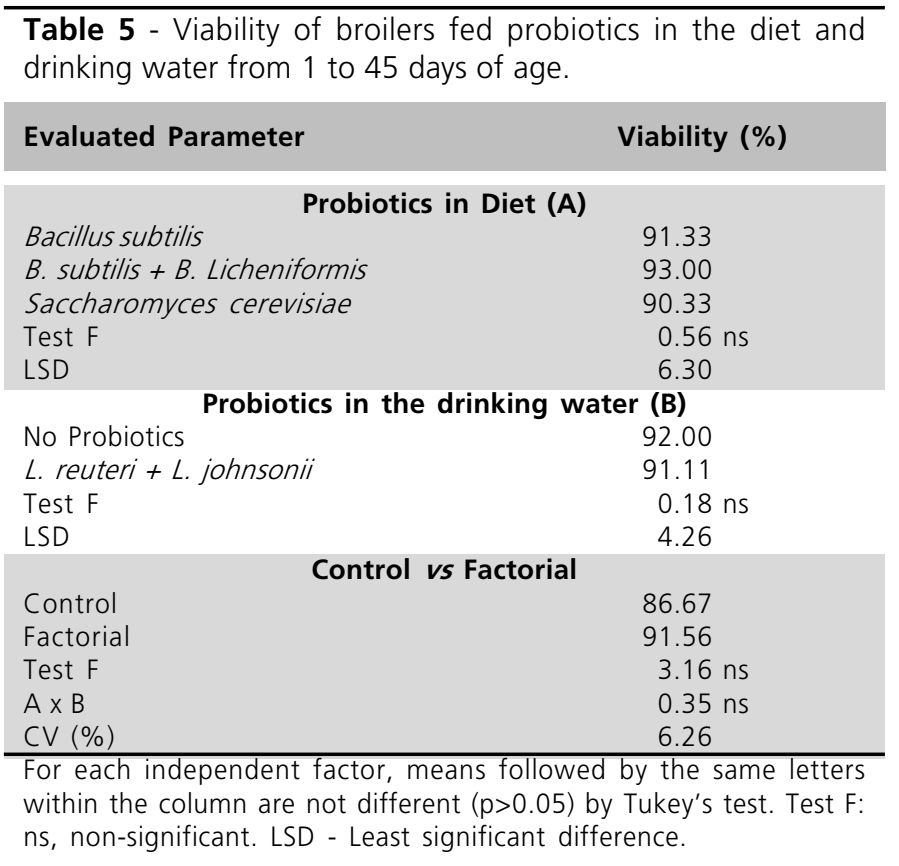

\section{CONCLUSIONS}

It was concluded that no beneficial effects of probiotics supplementation were seen on the performance.

\section{REFERENCES}

Barrow PA. Probiotics for chickens. In: Fuller, R. Probiotics, the Scientific Basis. Londres: Chapman \& Hall; 1992. p. 225-252

Besnard J, Auclair E, Larbier M. Effect of yeast supplementation on productive parameters of turkeys. In: World's Poultry Science Congress [CD-ROM]; 2000; Montreal, Canada:WPSA; 2000.

Biotecnal. O fantástico mundo dos probióticos: manual técnico, São Paulo; s.d. 66p.

Buenrostro JL, Kratzer FH. Effects of Lactobacillus inoculation and antibiotic feeding of chickens on availability of dietary biotin. Poultry Science 1983; 62:2022-2029.

Campos DMB, Faria Filho DE, Pinheiro JCA, Abe PT, Gadelha AC, Furlan RL, Macari M. Níveis de inclusão de probiótico (Bacillus subtilis) sobre o desempenho de frangos de corte. Revista Brasileira de Ciência Avícola 2002, suplemento 4, p. 36.

Cavazzoni V, Adami A, Castrovilli C. Performance of broiler chickens supplemented with Bacillus coagulans as probiotics. British Poultry Science 1998; 39:26-529.

Dale N. Probióticos para aves. Avicultura Profesional 1992; 10:8889.

Estat 2.0 Sistema de Análise Estatística. Jaboticabal: Polo 
Computacional, Departamento de Ciências Exatas, UNESP; 1992.

Fethiere R, Miles RD. Intestinal tract weight of chicks fed an antibiotic and probiotics. Nutrition Reports International 1987; 36:13051309.

Fox SM. Probiotics: intestinal inoculants for production animals. Veterinary Medicine 1988; 83:806-830.

Goldin, B.R. Health benefits of probiotics. British Journal of Nutrition 1998; 80(2):203-207.

Henrique APF, Faria DE, Franzolin R, Ito DT. Uso de probióticos e antibióticos como promotores de crescimento para frangos de corte. In: XXXV Reunião Anual da Sociedade Brasileira de Zootecnia; 1998; Botucatu; São Paulo. Brasil. Botucatu: Sociedade Brasileira de Zootecnia; 1998. p.297-299.

Jin LZ, Ho YM, Abdullah N, Jalaludin S. Growth performance, intestinal microbial populations, and serum cholesterol of broilers fed diets containing Lactobacillus cultures. Poultry Science 1998; 77:1259-1265

Leedle J. Probiotica and DFMs - mode of action in the gastrointestinal tract. In: Simpósio sobre aditivos alternativos na produção animal; 2000; Campinas, São Paulo. Brasil. Campinas: CBNA; 2000. p. 25-40

Loddi MM, Gonzales E, Takita TS, Mendes AA, Roça RO. Uso de probiótico e antibiótico sobre o desempenho, o rendimento e a qualidade da carcaça de frangos de corte. Revista Brasileira de Zootecnia 2000; 29(4):1124-1131.

Loddi MM. Probióticos, prebióticos e acidificante orgânico em dietas para frangos de corte. [tese]. Jaboticabal, (SP): Universidade Estadual Paulista, UNESP, 2003.

Maiorka A, Santin E, Sugeta SM, Almeida JC, Macari M. Utilização de prebióticos, probióticos ou simbióticos em dietas para frangos. Revista Brasileira de Ciência Avícola 2001; 3(1):75-82.

Maruta K. Probióticos e seus benefícios. In: Conferência Apinco de Ciência e Tecnologia Avícolas; 1993; Santos; São Paulo. Brasil. Campinas: FACTA; 1993. p. 203-219

Menten JFM. Probióticos, prebióticos e aditivos fitogênicos na nutrição de aves. In: II Simpósio sobre Ingredientes na Alimentação Animal; 2002; Uberlândia; Minas Gerais. Brasil. Uberlândia: CBNA/ UFV; 2002. p.251-275.

Mohan B, Kadirvel R, Natarajan A, Bhaskaran M. Effect of probiotics supplementation on growth, nitrogen utilization and serum cholesterol in broilers. British Poultry Science 1996; 37:395-401.

Moreira J, Mendes AA, Garcia EA, Garcia RG, Almeida ICL, JR. JGC. Efeito do uso do probiótico sobre o desempenho e rendimento de carcaça em frangos de corte. In: XXXVIII Reunião Anual da Sociedade Brasileira de Zootecnia, 2001; Piracicaba; São Paulo. Brasil. Piracicaba: SBZ; 2001. p.852-854.
Mulder RWAW. Probiotics as a tool against Salmonella contamination. Misset World Poultry 1991; 7:36-37.

NRC - National Research Council. Nutrient Requirements of Poultry. $9^{\text {th }}$ revised edition. Washington: National Academy Of Science Press; 1994. $156 p$

Padilha T. Resistência antimicrobiana $x$ produção animal: uma discussão internacional. In: Coletânea Resumos \& Debates. [capturado em 2000]. Disponível em: www.embrapa.br:8080/aplic. 2000

Pelicano ERL, Souza PA, Souza HBA. Prebióticos e probióticos na nutrição de aves. Ciências Agrárias e da Saúde 2002, 2(1):59-64.

Pelicano ERL, Souza PA, Souza HBA, Oba A, Leonel FR, Zeola NMBL Boiago MM. Utilização de probióticos e/ou prebióticos como promotores de crescimento em rações iniciais de frangos de corte. Revista Brasileira de Ciência Avícola 2004; suplemento 6, p. 17.

Santoso U, Tanaka K, Ohtani S. Effect of dried Bacillus subtilisculture on growth, body composition and hepatic lipogenic enzyme activity in female broiler chicks. British Journal of Nutrition 1995; 74:523529 .

Sato RN, Loddi MM, Nakaghi LSO. Uso de antibiótico e probiótico como promotores de crescimento em rações iniciais de frangos. In: Conferência Apinco de Ciência e Tecnologia Avícolas; 2002; Campinas; São Paulo. Brasil. Campinas: FACTA; 2002. p.37.

Silva EN. Probióticos e Prebióticos na alimentação de aves. In: Conferência Apinco de Ciência e Tecnologia Avícolas; 2000; Campinas, São Paulo. Brasil. Campinas: FACTA; 2000. p. 241-251.

Sogaard H, Suhr-Jessen T. Microbials for feed: Beyond lactic acid bacteria. Feed International 1999; 11(1):32-38

Sugeta SM, Bersch FX, Bueno CJC, Borges CAQ. Substituição dos promotores de crescimento por probióticos na dieta de frangos de corte. Revista Brasileira de Ciência Avícola 2004; suplemento 6, p. 53.

Visek WJ. The mode of Growth Promotion by Antibiotics. Journal of Animal Science 1978; 46:1447-1469.

Wolke LF, Flemming JS, Mira RT. Utilização do probiótico Bacillus natto como promotor de crescimento na alimentação de frangos de corte. Revista do Setor de Ciências Agrárias 1996; 15(1):103107.

Yeo J, Kim K. Effect of feeding diets containing an antibiotic, a probiotics or yucca extract on growth and intestinal urease activity in broilers chicks. Poultry Science 1997; 76:381-385. 